Hugoye: Journal of Syriac Studies, Vol. 14.1, 3-25

(C) 2011 by Beth Mardutho: The Syriac Institute and Gorgias Press

\title{
PAPERS
}

\section{A SOGHITHA ON THE DAUGHTER OF JEPHTHA, BY ISAAC}

\author{
SEBASTIAN BROCK
}

\section{INTRODUCTION}

In his survey of literary and musical treatments (the latter, in oratorios and opera) of the theme of the sacrifice of Jephtha's daughter Judges 11) from the $16^{\text {th }}$ to the $20^{\text {th }}$ century, W. O. Sypherd commented ${ }^{1}$ on the absence of any specifically literary (as opposed to primarily exegetical) treatments of the them between the striking Lament of Seila (the name given to the daughter) in Ps. Philo's Book of Biblical Antiquities XL.5-7 (first century AD) and Peter Abelard's 'Lament of the virgins of Israel over the daughter of Jephtha' in the early twelfth century, though he wisely added a footnote to the effect that 'other literary treatments of the story arising from this period of years may come to light at any time'. M. Alexiou and P. Dronke, in their study of the place of Seila's lament within the wider genre of the Planctus, were only able to supply a single additional example from the intervening eleven centuries, namely, the brief reference to Jephtha's daughter in Thecla's praise of virginity, in Methodius'

${ }^{1}$ W.O. Sypherd, Jephthah and his Daughter (Newark Delaware, 1948), p. 7. For the period covered he lists no less than 305 literary treatments of the theme and 174 musical ones! 
(d. 311) Symposium. ${ }^{2}$ In a footnote, however, they make reference to Ephrem's Carmina Nisibena 70, which contains the poet's longest passage on Jephtha's daughter. It is in fact in Syriac literature that some further important literary treatments of the theme are to be found, and in particular Jacob of Serugh devotes an entire memra to it. ${ }^{3}$ A further, much shorter poem, in the form of a soghitha in the $5+55+5$ metre, is to be found in an eighth- or ninth-century manuscript, Add. 17,141, in the British Library. The manuscript in question contains a large collection of verse texts, for the most part liturgical in character; several of these happen to be of considerable literary interest as well, such as the Dispute of the Months ${ }^{4}$ and the present poem, published here. ${ }^{5}$

The contents of the sogbitha on Jephtha's daughter can be set out as follows:

stanzas 1-3: A general statement is made concerning vows, stressing that they should be kept.

stanzas 4-6: Jephtha addresses the people, urging them to stand firm: in that case God will provide help. He also mentions the need for prayer to be offered by the women.

stanzas 7-8: The battle is joined and briefly described.

stanza 9: The role of the divine Prompting (remzo).

stanza 10: The old men and the wives lament their dead.

stanzas 11-12: On hearing of Jephtha's safe return his daughter goes out to meet him.

stanza 13: The arrival of Jephtha.

stanzas 14-15: Riders give praise to God for their safe return.

2 Alexiou and Dronke, 'The Lament of Jephtha's daughter', Studi Medievali 3e Serie, XII.2 (1971), pp. 851-2.

${ }^{3}$ Homily 159 (ed. Bedjan, V, pp. 306-30); an English translation and introduction, by S.A. Harvey and O. Mintz-Manor, is shortly to appear in the Gorgias Press series The Metrical Homilies of Mar Jacob of Sarug.

${ }^{4}$ Published in my 'A Dispute of the Months', Journal of Semitic Studies 30 (1985), pp.189-200; the poem interestingly combines two different genres, one Ancient Mesopotamian (the precedence dispute) and the other Greek (the ekphrasis, or description).

5 The text and translation are also given in the appendix of Harvey and Mintz-Manor's bilingual edition of Jacob's poem. 
stanzas 16-18: Jephtha's daughter welcomes her father who has risked his life.

stanzas 19-22: Jephtha, on seeing her, laments: if only he had died instead, whereas now he will have no heir.

stanzas 23-30: His daughter's joyful response: her father should not be grieved: his vow was sincere, and was not made under any compulsion. He should remember the case of Abraham and Isaac (stanzas 26-27). Using wording which deliberately suggests a parallel with Mary, the daughter states that she is going to God as his 'handmaid' who is 'sealed like a letter'; thus she will be freed from the abuse of the world. Furthermore, had her father been killed, then she would have been taken off in slavery.

stanza 31: Jephtha's dilemma of what to do is put in the form of a rhetorical question.

stanzas 32-34: The Elders urge him to substitute another sacrificial victim.

stanza 35: The poem ends abruptly with the daughter rebuking them for their evil advice.

Although this is not the place to discuss in any detail the exegetical tradition of Judges 11 (on which there is already a very large amount of secondary literature $)^{6}$, it will be necessary to look very briefly at an outline of the main trends that are to be found, above all within the Syriac tradition (for which some of the main passages are translated in the Appendix).

6 A particularly helpful survey of patristic, medieval and early reformation treatments is given by J.L. Thompson in the second chapter of his Writing the Wrongs. Women of the Old Testament among Biblical Commentators from Philo through the Reformation (New York, 2001), pp. 10078. For the Midrashic tradition, see V. Shulamit, 'The story of Jephthah's daughter in the Midrash', in A. Brenner (ed.), Judges: a Feminist Companion to the Bible (Sheffield, 1999), pp. 48-66, and for the later Jewish tradition, D. Marcus, Jephthah and his Vow (Lubbock Tx, 1986), and J. Berman, 'Medieval monasticism and the evolution of Jewish interpretation to the story of Jephthah's daughter', Jewish Quarterly Review 95 (2005), pp. 228-56. 


\section{(1) THE FATHER AND HIS VOW}

Much of the strictly exegetical tradition focuses its main attention on Jephtha, and in particular on his vow; here several different attitudes are to be found, notably:

- he was foolish; after all it might have been some inappropriate animal that met him first, such as a dog: this is already found in Ps. Philo (whose author has God himself complain!), and it turns up frequently in subsequent Jewish and Christian writers. ${ }^{7}$ Sometimes God is said to have allowed it for pedagogic reasons, to provide a warning against rash vows, or indeed to try to put an end to human sacrifices.

- he is praised for having kept to his promise. This is the approach of the soghitha, though there might be a hint of criticism concerning rash vows in stanza 2.

- he had made the vow expecting God to provide miraculously an animal victim, as in the case of Abraham (Gen. 22).

- Jephtha is neither blamed or praised for his vow.

- the purpose of the whole episode was to provide a type of salvation to come through Christ. Here three different typological patterns are to be found (see (3) below).

\section{(2) THE DAUghter}

In general in the exegetical tradition much less attention is paid to the daughter. Where comment is made, it is sometimes negative. Thus her period of mourning is a sign of weakness; ${ }^{8}$ a hint of this is also to be found in an encomium on women martyrs under Shapur II: 'The daughter of Jephtha wept over her virginity that departed with her; maybe it was on account of the marriage that she (never) attained. But do you rejoice that your virginity has departed with you [that is, in martyrdom]'?

7 Thus for example Midrash Genesis Rabbah LX.3 (where it is likewise God himself who is represented as complaining); among earlier Christian Greek authors, e.g. Origen, Selecta in Judices (Patrologia Graeca 12, col. 949), Theodoret, Quastiones in Judices XX; and in Syriac writers, Theodore bar Koni and the later commentators (see Appendix).

8 Thus Jerome, for whom see A. Penna, 'The vow of Jephthah in the interpretation of St Jerome', Texte und Untersuchungen 79 (1961), 164-5.

9 P. Bedjan, Acta Martyrum et Sactorum II (1891), p. 86. 
Specifically positive treatments of her are rare, and her long lament given by Ps. Philo is unique among pre-modern treatments of the theme (Abelard's Lament is put in the mouth of the virgins who accompany her, and not in her own mouth). It is in fact chiefly in the earlier Syriac writers where she fares best. Here, not surprisingly given his general sympathy for biblical women, ${ }^{10}$ Ephrem sets the trend in one extended treatment and two shorter references (see the Appendix); as often happened, his lead was followed by Jacob of Serugh. Although sympathetic to the daughter, Jacob is however, basically more concerned with the part of Jephtha, to whom he devotes considerably more space. This in fact serves well to highlight the unusual character of the present soghitha, where it is the daughter who is very much the central figure, and to whom most space is given.

It might be mentioned that there appears to be no trace in Syriac of the tradition that is found in Qimhi and some other medieval Jewish (and thence some Christian) exegetes that the daughter was not sacrificed, but ended up as a dedicated virgin. ${ }^{11}$ This interpretation has recently been shown to go back to the Karaite al-Qirqisani, writing in north Iraq in the $10^{\text {th }}$ century. ${ }^{12}$

\section{(3) TYPOLOGICAL PATTERNS:}

A number of different typological patterns may be found in the Syriac texts:

(a) Jephtha is a type of the Father: thus Jacob of Serugh (ed. Bedjan, p.315) and Theodore bar Koni.

(b) Jephtha is a type of Christ, having been 'persecuted' (the reference will be to Judges 11:2, where he is driven out of his father's house); thus Aphrahat.

(c) His daughter is a type of the Son: thus the Commentary ascribed to Ephrem, Jacob of Serugh (ed. Bedjan, p.313), a view

10 See further my 'St Ephrem on women in the Old Testament', in Saint Éphrem: un poète pour notre temps Patrimoine Syriaque: Actes du Colloque XI; Antélias, 2007), pp. 35-44.

${ }^{11}$ For this, see Marcus, Jephthah and his Vow.

12 See Berman, 'Medieval monasticism', pp. 228-56. The idea is actually hinted at in one of Gregory of Nazianzus' poems, where compares the sacrifice of the daughter to 'the offering of a chaste life to God' (Carmina II.94, in Patrologia Graeca 38, col. 56). 
mentioned by Theodore bar Koni which he says is also found among 'heretics', and Dionysius bar Salibi.

(d) Jacob and his daughter represent a combined type of Christ: thus Ephrem, Nisibene Hymns, no. $70 .{ }^{13}$

(e) A parallelism between Abraham and Isaac (Gen. 22) and Jephtha and his daughter, already in Ps. Philo, is also quite often found, and this may provide further typological links with Christ, either explicitly or implicitly. A famous pictorial example of this is provided by the parallel painted panels in St Catherine's Monastery, Sinai. ${ }^{14}$ In the soghitha, however, where the daughter reminds her father of Abraham and Isaac, there does not seem to be any further typological parallel hinted at.

In the martyr literature Jephtha's daughter is sometimes adduced alongside Isaac as a sacrificial model; a notable example concerns Cyrus, a martyr of the early Abbasid period, who 'went like a lamb to the [slaughter] beholding Isaac, the daughter of Jephthah, and, greater than all, [Christ, the Lord] of Isaac'. ${ }^{15}$

(f) Although never brought out explicitly, the soghitha hints at some sort of intended parallelism between the daughter and Mary. A few later texts compare her with Miriam going out to greet the victorious Israelites in Exodus 15, and possibly this link may then have suggested a parallelism with the Mary of the Gospels, though it may well instead have been the common theme of preserved virginity that lies behind this. These resonances are perhaps all the

13 It is interesting that this typological pattern also turns up in Maximus the Confessor's Quaestiones et Dubia (ed. J.H. Declerck, 1982), 33 (Jephtha corresponds to Christ's divinity, his daughter to Christ's flesh). For the daughter as a type of Christ, see especially C.B. Tkacz, 'Women as types of Christ: Susanna and Jephthah's daughter', Gregorianum 85 (2004), pp. 292-311, and '"Here I am, Lord". Preaching Jephtha's daughter as a type of Christ', Downside Review 434 (2006), pp.21-32.

${ }^{14} \mathrm{~K}$. Weitzmann, 'The Jephthah panel in the bema of the Church of St Catherine's Monastery on Mount Sinai', Dumbarton Oaks Papers 18 (1964), pp. 341-52.

15 Ps. Dionysius of Tel-Mahre, Chronicle (ed. Chabot), II, p. 399, translated in A. Harrak, The Chronicle of Zuqnin, Parts III and IV (Toronto, 1999), p. 334 (the folio in question is very damaged, hence the square brackets). 
more surprising in that no other typological links with the New Testament are present.

\section{THE AUTHOR}

It is well known that there are at least three Syriac poets of the fifth/sixth century named Isaac, and it may well be that yet a fourth should now be added, the 'Isaac the Solitary', fragments of whose poems turn up in the 'New Finds' from St Catherine's Monastery. ${ }^{16}$ The process of allocating the surviving poems to one or other of these Isaacs is still very much in its infancy, ${ }^{17}$ and at this stage it would be foolish to attempt to attribute the present soghitha to any particular one of them; this is all the more the case, seeing that, although there are some madrashe attributed to an Isaac, this is the first soghitha under this name.

Did Isaac know of Jacob's memra, or Jacob know of Isaac's soghitha? No clear evidence emerges from a comparison of the two. There are indeed a few common features, such as the description of Jephtha as a 'shepherd', but probably not enough to indicate some sort of literary dependence either way. The soghitha in fact exhibits some features which seem to be unparalleled elsewhere, such Jephtha's address to the people, with the need for the women's prayers (stanza 6) or the mention of the old men and wives lamenting their dead (stanza 10), or Jephtha's concern that the sacrifice of his daughter will mean that he will have no heir (stanza 21); likewise, the suggestion made by the Elders (stanzas 32-34) that Jephtha substitute an animal instead of his daughter.

\section{TEXT}

No other manuscript of the soghitha is known apart from British Library Add. 17,141 of the $8^{\text {th }} / 9^{\text {th }}$ century. The text is clearly corrupt in a few places, and on metrical grounds a word (or two) must have fallen out on two occasions. In the text below, what are

${ }^{16}$ M40N and Sparagma [Fragment] 34.

17 An instructive beginning has been made by T. Bou Mansour in a number of recent articles, e.g. 'Un clé pour la distinction des écrits des Isaac d'Antioche', Ephemerides Theologicae Lovanienses 79 (2003), pp. 365402. 
almost certainly original readings have been restored in several places, and the two lacunae have been tentatively filled, in accordance with the context. The standard orthography, nsh' has been restored in place of the unusual nysh' in stanzas 6 and 10 (this is normally to be found in later manuscripts of Melkite provenance). In every case the manuscript's reading is given in the apparatus that follows the text.

Add 17,141, ff. 104v-105r

$$
\begin{aligned}
& \text { תad }
\end{aligned}
$$

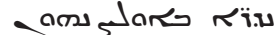

$$
\begin{aligned}
& \text { - amdwaina risl } \\
& \text { dras. as a }
\end{aligned}
$$

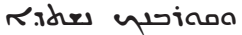

$$
\begin{aligned}
& \text { טitis } \\
& <\text { i.ar> > peon ods } \\
& \text { and atso } \\
& \text { هم }
\end{aligned}
$$

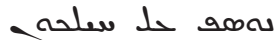

$$
\begin{aligned}
& \text { م Rivo }
\end{aligned}
$$

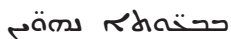

$$
\begin{aligned}
& \text { ris raids }
\end{aligned}
$$

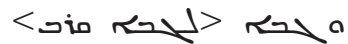

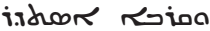

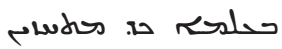

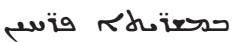

$$
\begin{aligned}
& \text { مarina }
\end{aligned}
$$

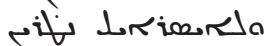

$$
\begin{aligned}
& \text { תרעם } \\
& \text { הتحلs }
\end{aligned}
$$

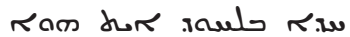

$$
\begin{aligned}
& \text { זיאד }
\end{aligned}
$$

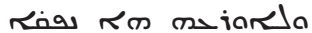

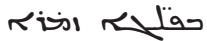

$$
\begin{aligned}
& \text { حil }
\end{aligned}
$$

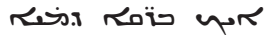

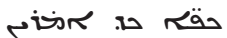

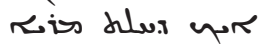

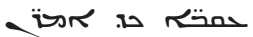

$$
\begin{aligned}
& \text { لحنقه xل }
\end{aligned}
$$

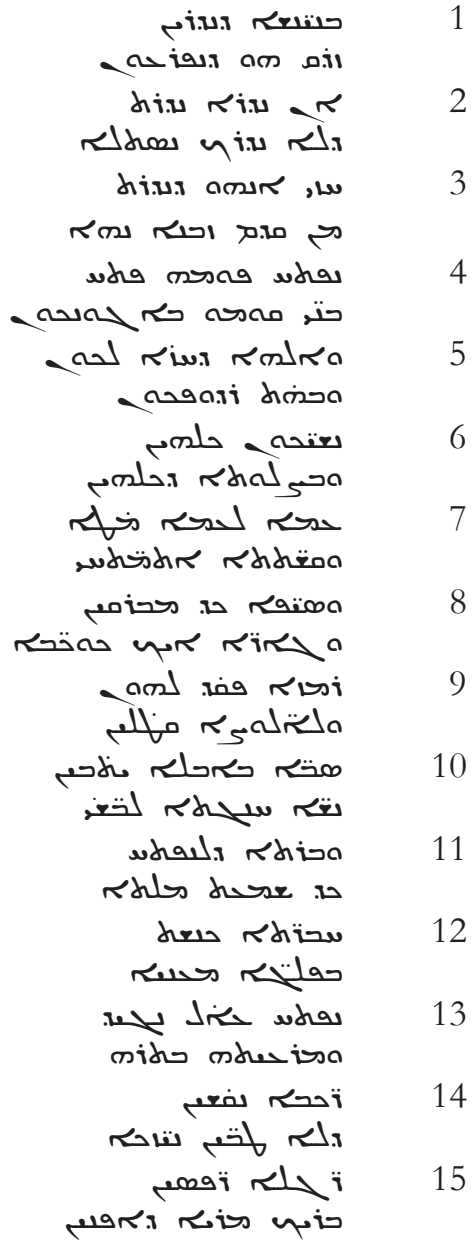




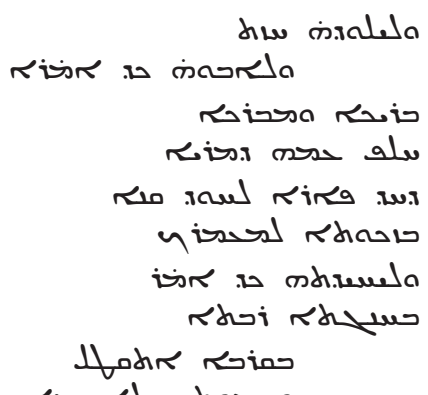

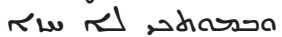

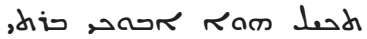
jan mbitiai iحder

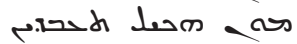

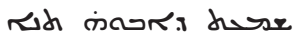

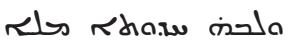

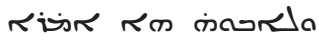
di.u diug difi ast rem

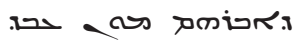

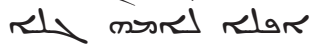

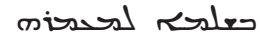
ممחic דים

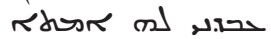
ק Rhosdw rdiver

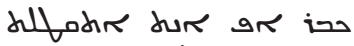
محله حمsis

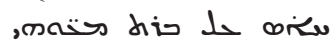

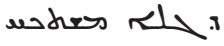

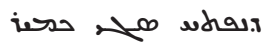
כerarers, dh cien roll

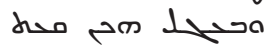
rivi red

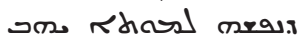

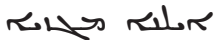
كiأب तो, काष

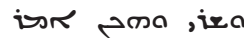

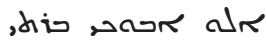
inodira, אa dasa

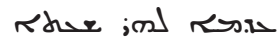
desc drex als raisl נחindir rhls rim Rhelf

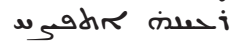

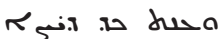
ملم. ه עr ז मा.

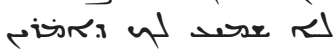
حה. م

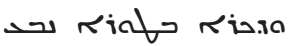
divi

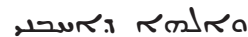
diiudira,

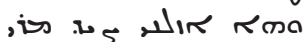
אח

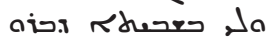
א

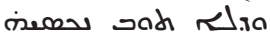

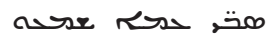

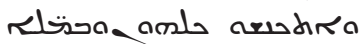
sedid as

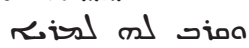
udieuel Rairo

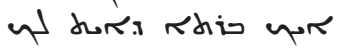

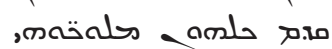

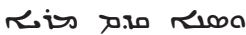


The following list gives the manuscript's reading in places where the text above departs from them:

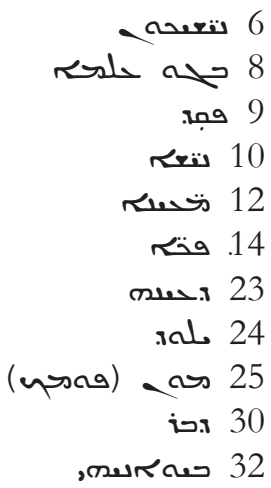

In stanzas 3 and 7, where the metre indicates that something has fallen out, possible suggestions have been supplied in angular brackets.

\section{TRANSLATION}

A sogbitha on the upright Jephtha and on his daughter, by Mar Isaac

1. People who make vows when they are in great straits should repay them to the Lord when they are at ease.

2. If you have made a vow, make ready what you are giving lest your vow be rejected and your offering refused.

3. Look and see, if you have made a vow to the Most High, let it be to the occasion, let it be set out and $<$ well $>$ ordered.

4. Jephtha opened his mouth and addressed them as follows, 'My children, stand firm in you contest, play true in your battle,

5. then God, who beholds you, will add to your strength and your oppressor will be put to shame, and your saviour will rejoice.

6. Let all your womenfolk busy themselves with supplications and through the prayer of them all the Lord will be pleased (or: reconciled)'.

7. One people encountered the other, one side <approached the other>;

the bows were stretched, and the battle lines drawn up;

8. swords glisten visibly in the world;

arrows like stars fly above the (two) camps. 
9. The (divine) Prompting gives them ${ }^{18}$ orders, and they act with discernment, they slay the oppressors, and they preserve Israel.

10. The old men sit there in grief as their sons have been slain, the women are clothed in grief as their husbands have been slaughtered.

11. Now Jephtha's daughter was the only one he had, and when she heard that her father had returned in peace

12 she gathered her companions and she goes out to meet him, she takes up the strain with tambourines, she sings with tambourines. ${ }^{19}$

13. In comes Jephtha, leading at the head, like a shepherd, ${ }^{20}$ with his flock behind him, resembling flashing lightning.

14. The riders ${ }^{21}$ clap their hands as they say 'Lances are not so fine as is the fear of the Lord'.

15. Feet trample, heels sound out, 'Blessed is the Lord who has brought us back to the eyes that watch out for us'.

16. The girl raised her eyes and beheld her parent; all at once she cried out as follows, saying to her father:

17. 'Welcome back, O blessed shepherd, truly blessed, who gave himself up to death for the sake of the Lord's own people.

18. O widowed tree that had one single fruit, blessed is the Lord who has brought you back in victory to your home'.

19. Jephtha lifted up his eyes, and catching sight of his only daughter

he began to say as follows amidst great groans:

20. 'If only, my daughter, your father had been slain in battle, had escaped by death and been buried, then he would not have beheld your death.

21. Up to that moment, my daughter, your father was confident that, should by chance he die, you would be his heir.

18 The 'arrows' will be the object of the verb here.

${ }^{19}$ Cf. Judges 11:34 (also Miriam in Exodus 15:21).

${ }^{20}$ Cf. Jacob, p. 310, line 11; Jephtha is again referred to as 'shepherd' in stanza 17.

${ }^{21}$ Perhaps an allusion to Exodus 15:1. 
22. I have vowed you to the Most High, what can now be done? You have been vowed to God, what can you do henceforth?

23. The girl, on hearing these words of her father, her mind rejoiced, her heart was filled with gladness;

24. leaping up, she answered her father and said, 'My parent, do not be grieved that you have made your vow to the Lord:

25. no one forced you to make it, you vowed it from your very heart.

Why are you complaining of being trapped by your mouth?

26. Have you not heard how they tell of what Abraham did when he took off his only son, without even revealing it to his mother?22

27. And how God returned him back home in peace while a ram burst forth on the mountain and was provided as an offering. ${ }^{23}$

28. You did not realise when you made the vow that I would meet you,

but God, who has loved me, has made me his handmaid. ${ }^{24}$

29. Blessed am I who have been freed from the abuse of this world

and now I am going to my Lord, a letter under seal..$^{25}$

22 Gen. 22:3. Isaac follows Ephrem, Comm. Gen. XX.1, in that he assumes that Abraham says nothing to Sarah; this contrasts with the scenario imagined in the two anonymous memre and the soghitha on Gen. 22; for the former see my 'Two Syriac verse homilies on the Binding of Isaac', Le Muséon 99 (1986), pp. 61-129, and for the latter 'Syriac poetry on biblical themes, 2: A dialogue poem on the Sacrifice of Isaac (Gen. 22)', The Harp 7 (1994), pp. 55-72.

23 The miraculous origin of the ram is already found in Ephrem's Commentary on Genesis XX.3; see further my 'Two Syriac verse homilies', pp. 78-9.

24 The daughter's wording in stanzas 28 and 29 clearly alludes to that of Mary in the Magnificat, Luke 1:38 ('handmaid') and 48 ('blessed').

25 Another clear allusion to Mary, who is likewise described as a 'sealed letter' in liturgical poetry: the precise phrase features in Jacob of Serugh (ed. Bedjan [reprint], VI, p. 24/639) in a passage which is taken up in both the Maronite Shehimto (Weekday Office) for Friday Lilyo (bo utho to First Qawmo), and in the Mosul edition of the Fenqitho, III, p. 354 (Commemoration of Mary of the Seeds). (There is an English translation 
30. Had it turned out that you had been defeated, then perhaps you would have been killed as well, and they would have taken me off in captivity and all our home would be destroyed'.

31. If he draws near to sacrifice her, will he have pity on the daughter of his loins?

But if he does not go on to slaughter her, he will be found false.

32. The elders of the people heard how Jephtha was greatly disconsolate

and so they all gathered and gave him solace with their words.

33. Jephtha, do not be grieved that you have made the vow to your Lord:

separate out some gift and give it; offer that to the Lord.

34. Give half your belongings, and leave your only daughter alone, for all that you possess is not so dear as this daughter you have'.

35. The girl said in answer before all those who had counselled him,

'How evil is your counsel, and odious before the Lord'.

\section{APPENDIX}

For purposes of comparison I provide here translations, but without discussion, of some more important passages in Syriac writers concerning Jephtha and his daughter.

\section{APHRAHAT, Demonstration 21:12:}

Jephtha too was persecuted, and Jesus was persecuted.

Jephtha's brothers had driven him out of the house of his father [Jud. 11:2];

Jesus' brothers drove him out, raised him up and crucified him. Jephtha the persecuted arose as head of his People; Jesus the persecuted arose and became King for the Peoples.

of Jacob's memra by M. Hansbury, Jacob of Serug on the Mother of God (Crestwood NY, 1998), pp. 38-9). For Mary as a 'letter', see further my 'Mary as a "Letter" and some other Letter imagery in Syriac liturgical texts', Vox Patrum 26 (2006) [Festschrift for M. Starowieyski], pp. 89-99. 
Jephtha vowed a vow and offered up his first-born daughter as an offering;

Jesus raised himself up as an offering to his Father on behalf of all the Peoples.

\section{EPHREM}

(a) Nisibene Hymns, 70:7-12 (following a reference to Gen. 22):

7. The case of Jephtha too is astonishing, the vine tender who plucked the grape cluster that had $<$ not (yet) $>26$ ripened and offered it to the Lord of the vineyard.

8. He offered it up, overcoming his feelings; his love compelled him, and he offered her up. He did not go out of his mind with suffering because his faithfulness upheld him.

9. The wine of death consists in the dregs stirred up with suffering: it makes its guests drunk with tears, those whom it invites, with weeping.

10. Jephtha's mighty type [Christ] gives much comfort for his offering up, by the sword, a treasure of life to her Lord.

11. Jephtha stretched out his right hand [cf. Gen. 22: 10] and offered up the sacrificial victim: the dove saw that he was greatly grieved and gave him courage with her utterance.

12. He was a fitting priest, acting as priest with blood (that originated) from himself to be a type for his Lord

${ }^{26}$ Since there is a play on the two senses of the verb be lat here, 'ripened' and 'married', and since the stichos is also one syllable short, I have conjecturally supplied a negative $(<$ dla $>$ be $l a t)$. 
who acted as priest with his own blood.

(b) Hymns on Virginity, 2:10-12 (addressed to consecrated virgins):

10. (In the case of) the daughter of Jephtha who bent down her neck to the sword, her pearl [virginity] comforted her, for it (thus) escaped from all kinds of terror and remained with her.

But here [in Ephrem's day] when (a girl) loses her pearl, grief is her companion at her death, and on the day of the Resurrection there is terror before the Judge when she repents.

11. The daughter of Jephtha was willing to die so that her father's vow might be fulfilled.

(O virgin), do not undo with your eyes the vow of virginity which your mouth has made, for your Betrothed has shed his own blood out of love for you.

See then how that blood of the Only-Begotten has bought that blood

by which your (virginity's) door is bought.

12. A married woman [Susanna] died to avoid adultery, A virgin died so that her father's vow might be fulfilled. ....

(c) Commentary on the Diatessaron (ed. L. Leloir), X.3:

People imitate those who perform good deeds, not out of love for the deeds, but out of the use (they bring). [The examples of Balaam (Num. 22-24) and the king of Moab (2 Kings 3:27) are given; the latter sacrificing his son in a time of crisis in imitation of Jephtha]. In the case of Jephtha, if one of his servants had met him first, he would have slain him, but in order that people should not sacrifice their fellow human beings, (God) let (Jephtha's) own daughter meet him, so that others should be afraid of vowing human beings to God. 
3. Commentary on Judges (wrongly attributed to Ephrem), ${ }^{27} \mathrm{ed}$. J.S.Assemani, I, cols. 321-2:

(Then) there Jephtha: some disorderly and wanton men got together (Jud. 11:3) (to go) to Jephtha, and the Elders of Gilead said to him, (Jud. 11:5) 'Come, be our leader, and we will fight the Ammonites' (Jud. 11:6). Jephtha, however, was not persuaded to go down as their leader because he saw that the People has rejected their idols but their repentance had not been accepted, nor had their petition, seeing that they had not found relief in their afflicted state: they had supplicated but had not received any reply, and they had not been delivered from servitude. (Jepththa) said to himself, 'Who am I that (God) should hear me, when he has not listened to Israel when they prayed before him?' Then he decided in himself as follows: he made a vow to the Lord, saying 'If you indeed should deliver the Ammonites into my hands, (then) whoever comes out of the door of my house to meet me when I come (back) safe and sound from the Ammonites shall belong to the Lord, and I will raise him up as a whole sacrifice to the Lord. That is, I am opening my mouth in a hidden way to the Lord, that whoever comes out first from my house to meet me, (him) will I offer up to Him. I am making this vow (just) between myself and God: henceforth it is up to God to prepare a sacrifice for his servant's victory, just as $\mathrm{He}$ once prepared a lamb for a whole offering [in place of Isaac, Gen. 22:13]'.

Consequently it is clear that he vowed one person from his household, and imagined that the Lord would prepare for him a sacrifice just as one he had prepared the lamb for the whole offering.

But when Jephtha returned to Mizpah, it was his own daughter who went out to meet him with tambourines and timbrels (Jud. 11:34). This was an ancient custom among the Hebrews: they would make a festival and celebrate as a token of victory, as it is earlier written how the prophetess Miriam, Moses' sister, took a tambourine in her hands (Ex. 15:20), and she and her companions gave praise to the Lord, responding to each other, for the victory

${ }^{27}$ For this Commentary (in Vatican Syr. 103), see especially R.B. ter Haar Romeny, 'The identity formation of Syrian Orthodox Christians as reflected in two exegetical collections', Parole de l'Orient 29 (2004), pp. $107-$ 108 ('the Collection of Symeon'). 
which God had granted to His people at the dividing of the Red Sea and the drowning of Pharaoh and his armies in the sea. Similarly when (Jephtha's daughter) heard that her father had been victorious, she went out to meet him with tambourines and timbrels. Again, after a time, when David vanquished the warrior Goliath and the Philistines were defeated, and David returned, along with king Saul and all the people, it is written that the young women ${ }^{28}$ were going out to meet them, responding with their tambourines and saying, 'Saul has killed in the thousands, but David in the ten thousands' (I Sam. 21:12).

As for (Jephtha's) rending his garments when he saw his daughter coming (to be) the sacrifice (Jud. 11:35), it is related among the people that, when he (prophetically) saw how Emmanuel had come, who in the latter days of the world offered himself in self-sacrifice in order to render sin ineffective, the symbolic garments in which he was wrapped were rent asunder. And again, the garments of the commander (Jephtha) which were rent have pointed us to the robe of the High Priest which was torn at the killing of our Lord, which put an end to the rule of the Synagogue.

Jephtha said, 'O my daughter, you have utterly ruined me today' (Jud. 11:35). But she said to him, 'Do with me according to what has issued from your mouth, now that the Lord has effected for you a requital over your enemies' (Jud. 11:36).

As for it not being the very same day on which he saw her that Jephtha offered her up as a sacrifice, this is because it was not the moment that the High Priests saw Him that they put Emmanuel to death, but (instead) they left him to travel about the regions of Israel and the mountains of the descendants of Jacob, weeping over their hardness of heart.

As for his daughter coming to him after two months (Jud. 11:39) and then being killed, (this) is because God came (as) man of his own will to those who crucified him, and it was not through the compulsion of other people.

The two months that she remained as a virgin and was not slain indicate the time of the Law and the time of the Prophets, it

${ }^{28}$ In the Hebrew text the subject of the verb is masculine, but the Peshitta has the feminine form and furthermore identifies the women as 'the daughters of Israel'. 
being sealed (i.e. assured) that the Messiah would come and die after (the time of) the Law and the Prophets.

4. THEODORE bar KONI, Book of Scholia (late $8^{\text {th }}$ cent.; ed. A. Scher, CSCO Scr. Syri 55; I, pp. 205-6):

Why was Jephtha neither praised nor blamed [i.e. in the biblical text] when he sacrificed his daughter?

He was not praised, because he made the vow to God without any discernment or thought for the consequences, 'Whoever comes out of the door of my house to meet me first of all, I will offer him up to the Lord'. Then what if (it were) a dog, or an ass, which are unclean in the Law, ${ }^{29}$ what would you do, Jephtha?

Nor was he blamed, because he was true to his covenant, and the love of God was more weighty in his eyes than (the feelings of) natural compassion.

He was not held back, as Abraham (was held back) from the slaughter of his son, one (reason being) that a person should not run over-confidently after his personal request; secondly, because God required it, to depict in him a type of the case of our Lord.

Now victory was granted to him over the Ammonites, not because of his vow, but to make the People victorious and defeat the People [Gentiles].

Some say that he vowed his daughter-especially the heretics - comparing the sacrifice of her with the Son of God. But these misguided people have not understood that, had he vowed her, he would never have said 'Alas, my daughter, you have utterly destroyed me'.

It is not her death that the Hebrew women mourn in the month of $\mathrm{Ab}$ [August], as some people suppose, but the destruction of Jerusalem.

${ }^{29}$ This derives from Theodoret, Quaestiones in Judices, XX. 
5. ISHO'DAD OF MERV, Commentary on Judges (mid 9 $^{\text {th }}$ cent.; ed. C. van den Eynde, CSCO Scr. Syri 96), pp. 32-3. (It will be noticed that Isho'dad either draws on Theodore, or (more likely) they are both using a common source):

It is likely that it was out of fear and misguidedness that this foolish Jephtha fell into (making) the vow: he was well aware that, according to custom at the time of victory women go out to meet (the men) with tambourines and timbrels, and (that) it might chance that a dog would go out of the house, or an unclean animal. Through all this it is evident that a vow ought to be (made) laxly.

The victory that occurred for Jephtha was not because of his vow, but because of the name of God, and (out of) His grace; or because of the repentance and mended ways of the People, and the condemnation of the erring Peoples.

He was neither praised nor blamed. He was not praised because it was without discernment or thought for the consequence that he made the vow to God. Nor was he accused, because he held firm to his covenant, and divine love was more honoured in his eyes than (feelings of) natural compassion.

He was not held back, as Abraham was from the killing (of Isaac), one (reason being) to teach that a person should not run over-confidently after his personal request; secondly, God required it, so as to depict in him a parable of our Lord.

Others praise him, as also does the Apostle (Hebrews 11:32), numbering him with the virtuous, alongside Samuel, David and the rest.

It is not her death that Hebrew women mourn in $\mathrm{Ab}$, as some have supposed, but the destruction of Jerusalem.

Now the pagans honour and worship the daughter of Jephtha, calling her Allat. ${ }^{30}$

30 Compare Epiphanius, Panarion LV.1.10, where he states that in Samaria she was worshipped as a goddess. 


\section{DIONYSIUS BAR SALIBI, Commentary on Judges} (Mingana Syr. 152, ff.78v-79r). ${ }^{31}$ The Commentary is in two columns, one 'factual', the other 'spiritual'. (It will readily be noticed that Dionysius and Bar 'Ebroyo also draw on the earlier East Syriac exegetical tradition):

(a) 'The Spirit of the Lord was upon Jephtha': that is, not for fear, but so that he might become valiant; (it was) not like something asked for, but so that he should not be afraid.

'And he vowed a vow': that is, his vow was unspecified, for he did not know what God wanted, saying (to God), 'I have vowed, and do you separate out from my household whomever you want; do you chose the sacrifice, and I will fulfil it'. The Accuser, seeing the unspecified nature of the vow, devised a way of setting a trap for Jephtha, (that would result in) transgression and distancing (him) from God: he incites (Jephtha') daughter to go out to meet him, so that, having pity on her, (Jephtha) would break his vow and (so) be condemned. He, however, on seeing her, was (indeed) griefstricken, and he tore his garments out of the love he had for her; but although his natural love was great, by fulfilling the will and through love of God he overcame this (natural) love.

'You have utterly destroyed me': that is, he shows that he is blaming 32 her.

'Do to me according to what has issued from your mouth': that is, I do not have the wish to build up your house so much as that your word should be true.

He did not sacrifice her on that very day, so that he should not be thought proud or haughty. This too is amazing, that he patiently held out and did not sacrifice her (at once); but he did not weaken from his vow and the obligation to God.

Jephtha was not praised for his vow because he made it without any distinction. If a dog, or an ass, which are unclean according to the Law, had gone out to meet him, would he have sacrificed them? He was not blamed because he was true to his vow and he honoured God more than his daughter. God allowed Jephtha's daughter to be sacrificed, even though he was not

31 According to Tkacz, 'Women as types of Christ', p. 299, there is also a translation in D.H. Schulze's unpublished Chicago thesis of 1930 on Dionysius' Commentary on the Historical Books.

${ }^{32}$ Reading $m$ 'addel for mshaddel ('coaxing'). 
pleased ${ }^{33}$, by way of teaching people that someone should not ever make an unspecified vow; also so that Jephtha's vow should be fulfilled and it (thus) be seen that he loves God; (accordingly) that sacrifice was not thought of as a sin for him, and God accepted his daughter treating it as a martyrdom.

(b) 'She went out to meet him': just as Miriam and her companions, when the sea was divided, clashed cymbals, and as happened in the time of David too.

'Jephtha tore his garments': a symbol of the People who, when they saw our Lord, the garments of virtue were torn off them, along with the robe of the High Priest, which he tore.

He did not sacrifice her on the day he saw her: a symbol of Christ who was not immediately crucified by the Jews, but he travelled around, weeping at their perdition.

She came subsequently as the sacrificial victim, a symbol of Christ who delivered himself up to death of his own will.

Her companions were weeping: a symbol of the souls who groaned over the killing of the Son.

The women made a memorial of Jephtha's daughter: a symbol of the Church which, in the four divisions of the years, makes commemoration of the death of our Lord. [ ...].

The Hebrew women in Ab do not weep for the daughter of Jephtha, but for the destruction of Jerusalem.

7. BAR 'EBROYO, Osar Raze (ed. J.Y. Çiçek, pp. 122-3):

Jephtha was not praised for his vow, in that he made the vow without any distinction: 'anyone who goes out to meet me from the door of the house, I will offer up as a whole offering'. Suppose an ass or a dog had gone out, what would he have done?

Nor was he blamed, in that he was true to his covenant; or (because) he held love of God to be more honoured than natural compassion.

He was not held back, as was the case with Abraham, so that people should be held back from making unspecified vows such as this. $[\ldots]$

From time to time the daughters of Israel used to go out and weep in lamentation for the daughter of Jephtha the Gileadite for

${ }^{33}$ Reading $r^{\prime} e$ for $d^{\prime \prime}$. 
four days each year. Today they weep in lamentation, not for the daughter of Jephtha, but for the destruction of Jerusalem.

8. As a single example of reference to Jephtha's daughter in liturgical poetry, I cite a qolo from the Commemoration of Shmoni (mother of the Maccabaean martyrs), on August 1 (Fenqitho, Mosul edition, VII, p. 302):

The upright Abram offered up as a sacrifice his son, Jephtha too, his virgin daughter, but Shmoni offered up her entire family as a whole offering. Blessed is the Good One who accepted them.

\section{BibliograPHY: SECONDARY WORKS Cited}

M. Alexiou and P. Dronke, 'The Lament of Jephtha's daughter: themes, traditions, originality', Studi Medievali 3a Serie, II.2 (1971), pp. 819-63.

J. Berman, 'Medieval monasticism and the evolution of Jewish interpretation to the story of Jephthah's daughter', Jewish Quarterly Review 95 (2005), pp. 228-56.

T. Bou Mansour, 'Un clé pour la distinction des écrits des Isaac d'Antioche', Ephemerides Theologicae Lovanienses 79 (2003), pp. 365402.

S.P. Brock, 'A Dispute of the Months and some related Syriac texts', Journal of Semitic Studies 30 (1985), pp. 181-211; reprinted in From Ephrem to Romanos: Interactions between Syriac and Greek in Late Antiquity (Aldershot, 1999), chapter VIII.

. 'Two Syriac verse homilies on the Binding of Isaac', Le Muséon 99 (1986), pp. 61-129; reprinted in From Ephrem to Romanos, chapter VI.

. 'Syriac poetry on biblical themes, 2: A dialogue poem on the Sacrifice of Isaac (Gen. 22)', The Harp 7 (1994), pp. 55-72.

. 'Mary as a "Letter" and some other Letter imagery in Syriac liturgical texts', Vox Patrum 26 (2006) [Festschrift for M. Starowieyski], pp.89-99.

. 'St Ephrem on women in the Old Testament', in Saint Éphrem: un poète pour notre temps (Patrimoine Syriaque: Actes du Colloque XI; Antélias, 2007)

M. Hansbury, Jacob of Serug on the Mother of God (Crestwood NY, 1998).

A. Harrak, The Chronicle of Zuqnin, Parts III and IV (Toronto, 1999). 
S.A. Harvey and O. Mintz-Manor, Jacob of Sarug's Homily on Jephthah and his Daughter (Piscataway NJ, forthcoming).

D. Marcus, Jephthah and his Vow (Lubbock Tx, 1986).

A. Penna, 'The vow of Jephthah in the interpretation of St Jerome', Texte und Untersucbungen 79 (1961), pp. 162-71.

V. Shulamit, 'The story of Jephthah's daughter in the Midrash', in A. Brenner (ed.), Judges: a Feminist Companion (Sheffield, 1999), pp. 48-66.

W.O. Sypherd, Jephthah and his Daughter. A Study in Comparative Literature (Newark, Delaware, 1948).

C.B. Tkacz, 'Women as types of Christ: Susanna and Jephthah's daughter', Gregorianum 85 (2004), pp. 278-311.

. “Here I am, Lord”. Preaching Jephthah's daughter as a type of Christ', Downside Review 434 (2006), pp. 21-32.

R.B. ter Haar Romeny, 'The identity formation of Syrian Orthodox Christians as reflected in two exegetical collections: first soundings', Parole de l'Orient 29 (2004), pp. 103-21.

K. Weitzmann, 'The Jephthah panel in the bema of the Church of St Catherine's Monastery on Mount Sinai', Dumbarton Oaks Papers 18 (1964), pp. 341-52. 
